\title{
Organochlorine pesticide contamination in marine organisms of Yantai coast, northern Yellow Sea of China
}

\author{
Jing Chen • Linlin Chen • Dongyan Liu • \\ Gaosheng Zhang
}

Received: 19 April 2013 /Accepted: 1 October 2013 /Published online: 15 October 2013

(C) Springer Science+Business Media Dordrecht 2013

\begin{abstract}
To evaluate the contamination of organochlorine pesticides (OCPs) in marine organisms and their potential health risk on consumers in the northern Yellow Sea of China, mollusks, wild shrimps, and crabs were collected from the Yantai coast, and the OCP contents in the samples were analyzed and compared. The results indicate that all the samples have been contaminated by OCPs, and OCP concentrations varied in individual species and in sampling sites. Among the studied OCPs, $\sum \mathrm{HCH}$ and $\sum \mathrm{DDT}$ concentrations ranged from 0.91 to $13.92 \mathrm{ng} \mathrm{g}^{-1}$ and from 10.16 to $411.19 \mathrm{ng} \mathrm{g}^{-1}$, respectively. Meretrix was highly enriched with $\mathrm{HCHs}$, while the highest DDT concentration was found in Crassostrea. For the OCP isomers, $\beta-\mathrm{HCH}$ was the predominant isomer of $\mathrm{HCHs}$, and $p, p^{\prime}$-DDE concentration was much higher than other
\end{abstract}

J. Chen $\cdot$ L. Chen $\cdot$ D. Liu $\cdot$ G. Zhang

Key Laboratory of Coastal Environmental Processes and Ecological Remediation, Yantai Institute of Coastal Zone Research (YIC), Chinese Academy of Sciences (CAS), Yantai, Shandong 264003, People's Republic of China

J. Chen $\cdot$ L. Chen $\cdot$ D. Liu $\cdot$ G. Zhang

Shandong Provincial Key Laboratory of Coastal Environmental Processes, Yantai Institute of Coastal Zone Research (YIC), Chinese Academy of Sciences (CAS), Yantai, Shandong 264003, People's Republic of China

G. Zhang $(\bowtie)$

17 Chunhui Road, Laishan District, Yantai, Shandong 264003, People's Republic of China

e-mail: gszhang@yic.ac.cn isomers of DDTs. The concentrations of other OCPs (HCB, t-CHL, endrin, and mirex) were relatively low. For the shrimp and crab samples, Alpheus distinguendus samples accumulated a higher level of $\mathrm{HCHs}$ but lower DDTs than Oratosquilla aratoria and Carcinoplax vestitus in all sampling areas. HCHs in the samples of contrast area were not significantly lower than that of the sewage outfall area and port area, whereas DDTs in the samples of contrast area were relatively lower than that of the other two areas. Generally, all the OCP contents in the samples are in the range of the edible hygienic criteria except the total concentration of DDTs in Crassostrea.

Keywords Organochlorine pesticides · Pollution monitoring $\cdot$ Marine organisms $\cdot$ Northern Yellow Sea

\section{Introduction}

Organochlorine pesticides (OCPs) are ubiquitous anthropogenic contaminants that are persistent in the environment, even though production and use of OCPs have been banned for some decades in many countries (Tanabe et al. 1994; Wong et al. 2005). Due to their lipophilic nature, hydrophobicity, and low chemical and biological degradation rates, their accumulation in biological tissues and subsequent magnification of concentration in organisms progressing up in the food chain induce multiple health hazards to humans and animals (Binelli and Provini 2003). Highly toxic OCPs can cause acute poisoning including tremors, headache, dermal irritation, respiratory 
problems, dizziness, nausea, and seizures. Less toxic OCPs are associated with many chronic diseases, which include various types of cancer, neurological damage, Parkinson's disease, birth defects, respiratory illness, and abnormal immune system function (Chopra et al. 2011). These chemicals also impose various adverse effects in marine organisms, and their introduction into marine ecosystems arise from direct discharge (point sources), discharge to municipal sewage systems or rivers and venting to the atmosphere (Iwata et al. 1993). Marine organisms can accumulate contaminants from their environment and food chain; some of them can be used to indicate the pollutant levels (Zhang et al. 2009; SzlinderRichert et al. 2008; Leng et al. 2009). Therefore, it is important to evaluate OCP content and monitor their accumulation in the marine environment and organisms for seafood safety and the health of consumers.

Sishili Bay (SB) is an important shallow cultivation area in northern Yellow Sea, China, which is subject to the rapid industrialization, urbanization, and population development of the surrounded Yantai city. Persistent organic pollutants (POPs) that are released from the intensive agricultural and industrial activities have stressed the surrounding coastal ecosystems and have been regarded as one of the pollutant sources impacting the health of marine coastal environment and organisms (Fung et al. 2004; Liu et al. 2012). Previous studies have showed that the increased POPs along the Yantai coast could cause potential risk for the seafood (Wan et al. 2005a; Liu et al. 2008; Leng et al. 2009). SB is an important aquaculture bay, which supports the seafood market in Yantai and adjacent cities. It is essential to evaluate the OCP content in the marine organisms along the Yantai coast for seafood safety. In this study, mollusks, wild shrimps, and crabs were collected from a local seafood market and from the field in the SB, respectively. The OCP concentration in wild and aquacultured organisms were analyzed and compared, aiming to monitor the seafood safety and assess the potential risk to human health.

\section{Materials and methods}

Sampling sites and sample collection

For comparison with the different marine environments, sampling areas were designed in the sewage outfall area, Yantai port area, and less human activity area as the contrast area (Fig. 1). Two species of shrimps (Oratosquilla aratoria and Alpheus distinguendus) and one species of crab (Carcinoplax vestitus) samples were collected by net hauling from the three locations (A: sewage outfall area, B: port area, and C: contrast area). For comparison, seven kinds of mollusks (Mytilus edulis, Scapharca subcrenata, Crassostrea, Sol sricus, Saxidomus purpuratus, Meretrix meretrix, and Chiamys farrer) from the aquaculture in the bay were purchased from the local seafood markets of Yantai. These marine organisms are invertebrate species. Shrimps and crabs are omnivorous mainly eating zooplankton and benthic organisms, and mollusks feed mainly on zooplankton (Wan et al. 2005b).

Each kind of marine organism contained at least 30 individuals. All samples were placed for approximately $24 \mathrm{~h}$ in filtered seawater. This allowed them to empty their gut, without eliminating hydrophobic contaminants. The samples were placed in polyethylene bags and frozen at $-20{ }^{\circ} \mathrm{C}$ until chemical analysis. Prior to extraction, shucked mollusk samples were homogenized and freeze-dried. Subsamples were dried to constant weight to determine the water contents and eventually were ground into fine powder. The shrimp and crab samples were homogenized with their whole bodies.

\section{Chemical analysis}

The pretreatment was conducted, according to the method by Tanabe et al. (2000). Approximately $10 \mathrm{~g}$ of well-homogenized soft tissues were mixed with anhydrous $\mathrm{Na}_{2} \mathrm{SO}_{4}$, until the homogenate was freeflowing. The mixtures were extracted using $80-\mathrm{ml}$ hexane-dichloromethane mixture $(1: 1 \mathrm{v} / v)$ with sonication method for $60 \mathrm{~min}$ and then stood overnight. $p, p^{\prime}$-DDD, $p, p^{\prime}$-DDE, dieldrin, endrin, oxy-chlordane, and heptachlor were added as surrogates prior to the extraction. The extract was concentrated on a rotary evaporator to about $1 \mathrm{ml}$. The concentrated extract was further purified by elution through a glass column (12 mm i.d.) filled with 2-g silica gel. The extract was eluted using $20 \mathrm{~mL} n$-hexane and $20 \mathrm{~mL} \mathrm{3:1}$ (v/v) $n$-hexane/dichloromethane. The two fractions were combined, and the volume of samples was adjusted to about $1 \mathrm{~mL}$ by a gentle stream of nitrogen gas.

The quantification of OCP was measured using an Agilent 890A gas chromatograph (GC) with a ${ }^{63} \mathrm{Ni}$ electron capture detector (micro-ECD) (Agilent, USA). 


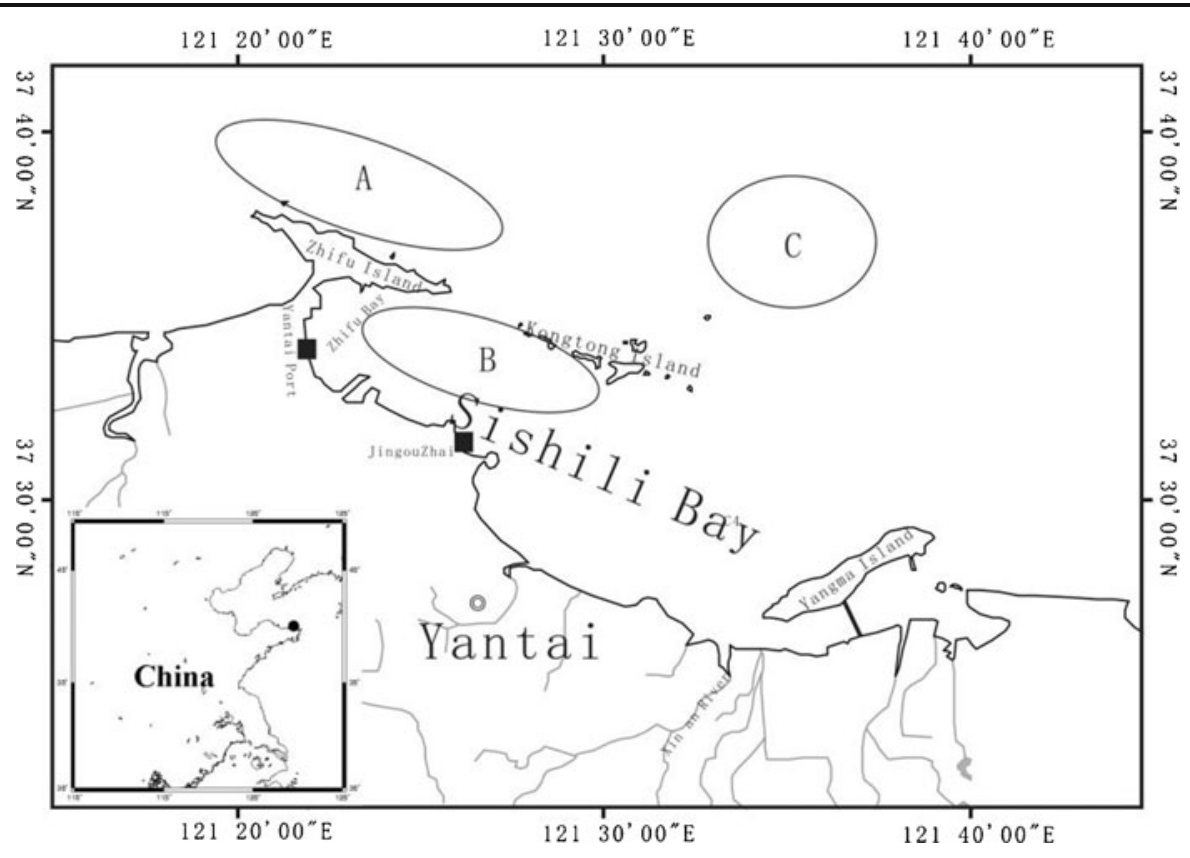

Fig. 1 The sampling sites in Yantai Sishili bay for collecting wild marine organisms: $A$ sewage outfall area, $B$ port area, $C$ contrast area

A HP-1 fused silica capillary column $(60 \mathrm{~m} \times 0.25 \mathrm{~mm}$ i.d., $0.25-\mu \mathrm{m}$ film thickness) was used for separation with high purity $\mathrm{N}_{2}$ as the carrier gas and make-up gas at a flow rate of 1 and $49 \mathrm{~mL} \mathrm{~min}^{-1}$. One milliliter of the extracts was injected into the injector at $250{ }^{\circ} \mathrm{C}$ with programmable temperature vaporization (PTV). The oven temperature was raised from 80 to $200{ }^{\circ} \mathrm{C}$ at a rate of $10{ }^{\circ} \mathrm{C} \mathrm{min}^{-1}$, hold for $1 \mathrm{~min}$, programmed to $270{ }^{\circ} \mathrm{C}$ at $5{ }^{\circ} \mathrm{C} \mathrm{min}{ }^{-1}$, and then hold for $5 \mathrm{~min}$. The injector and detector were maintained at 250 and $280{ }^{\circ} \mathrm{C}$, respectively. GC peaks were identified with the accurate assignment of retention times of OCP standards (the National Research Center for Certified Reference Materials of China) and further confirmed by an Agilent $6890 \mathrm{~N}$ GC-MS system. The residues of OCPs were quantitatively determined by the calibration curves of the standards using peak areas. The quantitative determinations were performed by internal standard procedure.

One procedural blank and one spiked blank consisting of all chemicals were run with every batch of ten samples to assess potential sample contamination. Results show that no target compounds were detected in laboratory blanks and three duplicate samples reported RSDs within $20 \%$ for all the target chemicals. The average recoveries of surrogate standards varied from 95 to $110.4 \%$. Reported values were not corrected by surrogate recovery. The detection limit was $0.01 \mathrm{ng} \mathrm{g}^{-1}$ based on dry weight.

\section{Results and discussion}

$\mathrm{HCH}$ and DDT concentrations in mollusks

HCHs, DDTs, and their derivatives have been subjected to intensive study worldwide over the last 10 years. They are regarded as environmental hormones which can disturb the reproductive cycles of human and wildlife (Binelli and Provini 2003). Descriptive statistics of $\mathrm{HCH}$ and DDT contents identified in mollusks collected from the local seafood market are listed in Table 1, and the percentages of organochlorine isomers of $\mathrm{HCHs}$ and DDTs are shown in Fig. 2.

The concentration range of $\mathrm{\Sigma HCHs}$ was $0.91-$ $13.92 \mathrm{ng} \mathrm{g}^{-1}$, with a median value of $5.17 \mathrm{ng} \mathrm{g}^{-1}$. The total concentrations of HCHs in M. meretrix (Mer.) were the highest among all mollusks, followed by Crassostrea (Cra.), M. edulis (Myt.), S. sricus (Sol.), and $C$. farrer (Chi.). The concentrations of HCHs were below the detection limit value $100 \mathrm{ng} \mathrm{g}^{-1}$. Among $\mathrm{HCH}$ isomers, $\alpha-\mathrm{HCH}, \beta-\mathrm{HCH}, \gamma-\mathrm{HCH}$, and $\delta-\mathrm{HCH}$ were detected in all mollusks, and $\beta-\mathrm{HCH}$ was the predominant isomer, varying from 0.60 to $5.42 \mathrm{ng} \mathrm{g}^{-1}$. 
Table $1 \mathrm{HCH}$ and DDT contents in mollusks (ng $\mathrm{g}^{-1}$ d.w.) collected from the seafood market of Yantai Sishili Bay, China

\begin{tabular}{lrrrrrrr}
\hline & Myt. & Sca. & Cra. & Sol. & Sax. & Mer. & Chi. \\
\hline$\alpha-\mathrm{HCH}$ & 0.90 & 0.18 & 0.97 & 0.32 & 0.24 & 1.57 & 0.52 \\
$\beta-\mathrm{HCH}$ & 2.56 & 0.60 & 4.69 & 3.62 & 0.85 & 5.42 & 3.03 \\
$\gamma-\mathrm{HCH}$ & 0.91 & 0.10 & 0.43 & 0.17 & 0.14 & 1.22 & 0.29 \\
$\delta-\mathrm{HCH}$ & 1.14 & 0.03 & 0.23 & 0.14 & 0.08 & 5.71 & 0.14 \\
$\sum \mathrm{HCHs}^{\mathrm{a}}$ & 5.51 & 0.91 & 6.32 & 4.25 & 1.31 & 13.92 & 3.98 \\
$p, p^{\prime}-\mathrm{DDT}$ & 32.05 & 7.60 & 132.84 & 6.40 & 2.13 & 12.26 & 1.36 \\
$o, p^{\prime}-\mathrm{DDT}$ & 10.18 & 2.77 & 39.99 & 1.16 & 0.60 & 3.58 & 6.57 \\
$p, p^{\prime}-\mathrm{DDD}$ & 31.19 & 5.44 & 116.85 & 35.72 & 1.74 & 25.64 & 4.96 \\
$o, p^{\prime}-\mathrm{DDD}$ & 10.40 & 3.86 & 35.00 & 7.30 & 0.58 & 8.50 & 7.59 \\
$p, p^{\prime}-\mathrm{DDE}$ & 25.91 & 14.53 & 81.61 & 23.79 & 4.90 & 16.21 & 14.20 \\
$o, p^{\prime}-\mathrm{DDE}$ & 1.95 & 2.79 & 4.90 & 1.05 & 0.21 & 1.06 & 1.84 \\
$\sum \mathrm{DDTs}$ & 111.68 & 36.99 & 411.19 & 75.42 & 10.16 & 67.25 & 36.52 \\
\hline
\end{tabular}

${ }^{\text {a }}$ Sum of $\alpha-, \beta-, \gamma-$, and $\delta-\mathrm{HCH}$

${ }^{\mathrm{b}}$ Sum of $p, p^{\prime}$-DDT, $o, p^{\prime}$-DDT, $p, p^{\prime}-\mathrm{DDD}, o, p^{\prime}$-DDD, $p, p^{\prime}$-DDE, and $o, p^{\prime}$-DDE

Typical commercial HCHs contain $\beta$-isomer of 5-14 \% (Willett et al. 1998), whereas $\beta-\mathrm{HCH}$ accounted for $38.9-85.2 \%$ of the total HCHs in this study. The reasons for the high percentage of $\beta-\mathrm{HCH}$ are that $\beta-\mathrm{HCH}$ is slow in biological and chemical degradation, has lowest water solubility and vapor pressure, is most stable, resistant to microbial degradation, and accumulated in organisms at high concentration (Simonich and Hites 1995; Willett et al. 1998). In addition, $\alpha-\mathrm{HCH}$ is transformed into $\beta-\mathrm{HCH}$ (Wu et al. 1997); this is consistent with the fact that $\beta-\mathrm{HCH}$ is detected as a predominant isomer in mussel, sediments, and human tissues (Smeds and Saukko 2001; Zhang et al. 2002; Rajendran et al. 2005; Jin et al. 2008).

Contrasted with HCHs, mollusk tissues showed high levels of DDTs. $\sum$ DDT concentrations ranged from 10.16 to $411.19 \mathrm{ng} \mathrm{g}^{-1}$, with a median value of $107 \mathrm{ng} \mathrm{g}^{-1}$.

The highest $\sum$ DDT concentration was found in Cra., which was over two times higher than the edible hygienic criteria $200 \mathrm{ng} \mathrm{g}^{-1}$ d.w. Considerable residues of DDTs found in all mollusk samples may indicate the presence of significant current sources of DDTs in Sishili Bay. Among DDT isomers, $p, p^{\prime}$-DDD, $p, p^{\prime}$ DDT, and $p, p^{\prime}$-DDE were the predominant isomers, accounting for $29.6,26.0$, and $24.2 \%$ of the total DDTs, respectively. The average (DDD+DDE)/DDT ratio in bivalves was 1.9 , showing that the composition of degradation products was higher than that of the mother compound. This means that technical DDTs used in the past are in the process of degradation in the environment. Although DDTs has been banned to use as agricultural chemicals in China since 1983, high concentration of DDTs has been observed in various environmental media, suggesting illegally continued usage of DDTs in China (Wong et al. 2005). Several other studies have also reported high DDT residues in sediments or animal tissues and revealed new inputs of DDTs in China (Klumpp et al. 2002; Mai et al. 2002; Yang et al. 2004). In addition, the bivalves have different accumulating abilities for organochlorines. The bioaccumulation of HCHs and DDTs are species-specific due to their ecological characteristics such as feeding habits and habitat (Yang et al. 2006); hence, Cra. and Mer. may be regarded as a bioindicator of DDTs and $\mathrm{HCHs}$ for marine pollution monitoring, respectively.

(a)

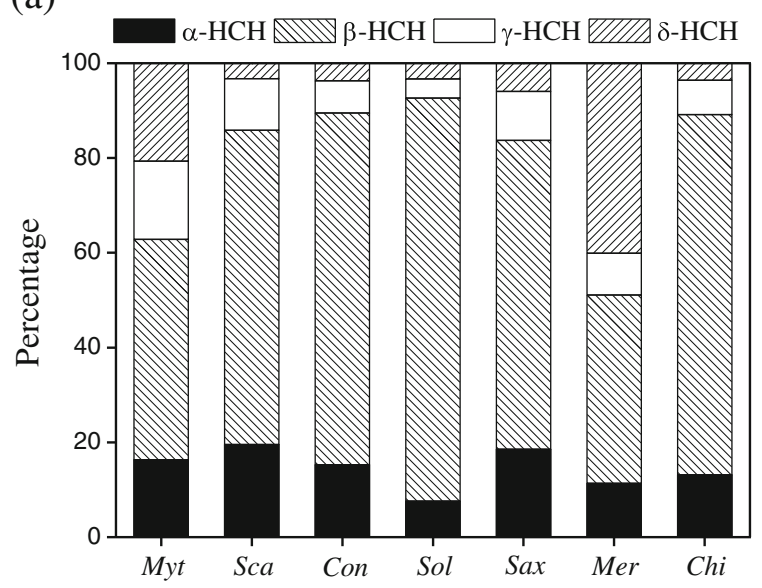

(b)

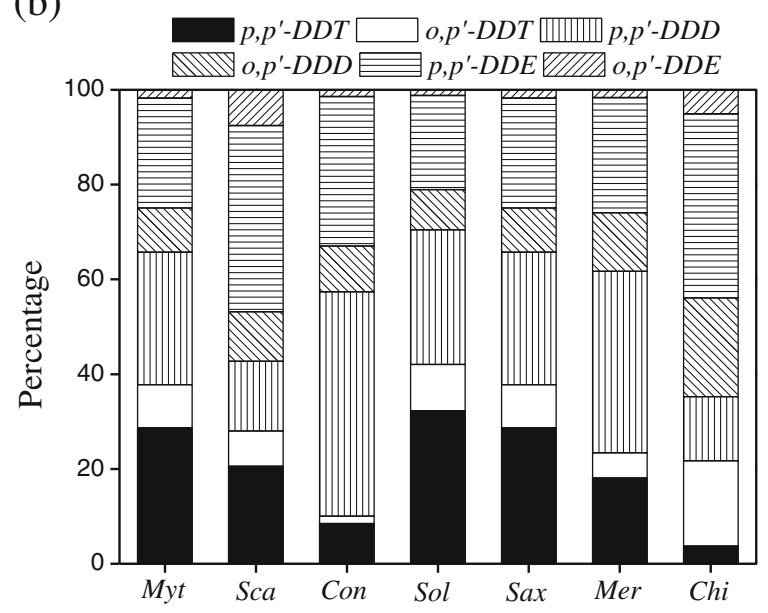

Fig. $2 \mathrm{HCH}$ (a) and DDT (b) compositions in mollusks collected from the seafood market of Yantai Sishili Bay, China 
Table $2 \mathrm{HCH}$ and DDT contents in shrimp and crab samples (ng $\mathrm{g}^{-1}$ d.w.) collected from three sampling sites in Yantai Sishili Bay, China
${ }^{\mathrm{a}} \mathrm{Sum}$ of $\alpha-, \beta-, \gamma-$, and $\delta-\mathrm{HCH}$

${ }^{\mathrm{b}} \mathrm{Sum}$ of $p, p^{\prime}$-DDT, $o, p^{\prime}$-DDT, $p, p$ -DDD, $o, p^{\prime}$-DDD, $p, p^{\prime}$-DDE, and $o, p^{\prime}-\mathrm{DDE}$

\begin{tabular}{|c|c|c|c|c|c|c|c|c|c|}
\hline & \multicolumn{3}{|c|}{ Sewage outfall area (A) } & \multicolumn{3}{|c|}{ Port area $(\mathrm{B})$} & \multicolumn{3}{|c|}{ Contrast area $(\mathrm{C})$} \\
\hline & Ora. & Alp. & Car. & Ora. & Alp. & Car. & Ora. & Alp. & Car. \\
\hline$\alpha-\mathrm{HCH}$ & 0.34 & 2.14 & 0.12 & 0.27 & 2.15 & 0.12 & 0.24 & 1.83 & 0.11 \\
\hline$\beta-\mathrm{HCH}$ & 1.62 & 1.82 & 2.44 & 1.63 & 1.44 & 0.94 & 1.63 & 1.33 & 2.02 \\
\hline$\gamma-\mathrm{HCH}$ & 0.22 & 0.55 & 0.08 & 0.31 & 0.43 & 0.09 & 0.16 & 0.41 & 0.10 \\
\hline$\delta-\mathrm{HCH}$ & 0.10 & 0.11 & 0.02 & 0.10 & 0.13 & 0.01 & 0.09 & 0.09 & 0.04 \\
\hline$\sum \mathrm{HCHs}^{\mathrm{a}}$ & 2.28 & 4.62 & 2.66 & 2.31 & 4.15 & 1.16 & 2.12 & 3.66 & 2.27 \\
\hline$p, p^{\prime}$-DDT & 15.89 & 3.14 & 8.51 & 27.55 & 10.72 & 5.68 & 12.63 & 7 & 3.73 \\
\hline$o, p^{\prime}$-DDT & 2.09 & 0.28 & 0.8 & 3.62 & 0.88 & 0.21 & 1.74 & 0.27 & 0.23 \\
\hline$p, p^{\prime}$-DDD & 12.63 & 4.18 & 11.67 & 22.58 & 7.56 & 4.66 & 9.68 & 5.35 & 4.55 \\
\hline$o, p^{\prime}$-DDD & 4.34 & 0.19 & 0.33 & 9.39 & 0.43 & 0.17 & 3.72 & 0.15 & 0.12 \\
\hline$p, p^{\prime}-\mathrm{DDE}$ & 16.84 & 20.06 & 72.91 & 37.52 & 23.91 & 43.63 & 14.27 & 13.31 & 40.01 \\
\hline$o, p^{\prime}-\mathrm{DDE}$ & 0.3 & 0.35 & 0.66 & 0.74 & 0.25 & 0.31 & 0.27 & 0.28 & 0.32 \\
\hline$\sum \mathrm{DDTs}^{\mathrm{b}}$ & 52.09 & 28.2 & 94.88 & 101.4 & 43.75 & 54.66 & 42.31 & 26.36 & 48.96 \\
\hline
\end{tabular}

$\mathrm{HCH}$ and DDT concentrations in shrimps and crabs

Contents of HCHs and DDTs in the shrimps and crabs which were collected from three sites by net hauling are shown in Table 2, and the percentages of individual isomers of HCHs and DDTs are illustrated in Fig. 3. $\mathrm{HCH}$ and DDT contents varied in individual species and in sampling sites.

$\sum \mathrm{HCH}$ and $\sum \mathrm{DDT}$ concentrations ranged from 1.16 to $4.62 \mathrm{ng} \mathrm{g}^{-1}$ and from 26.36 to $101.4 \mathrm{ng} \mathrm{g}^{-1}$ with a mean value of 2.80 and $54.73 \mathrm{ng} \mathrm{g}^{-1}$, respectively. In the same sampling site, it was found that $A$. distinguendus (Alp.) accumulated a higher level of $\sum \mathrm{HCHs}$ but lower $\sum$ DDTs than C. vestitus (Car.) and O. aratoria (Ora.). In the shrimp and crab samples investigated, the total level of the $\mathrm{HCH}$ isomers was dominated by $\beta-\mathrm{HCH}$ (>70\%), except for samples of Alp. For the DDT isomers, $p, p^{\prime}$-DDE concentration was much higher than those of other isomers. As far as the sampling locations are concerned, the concentration of $\sum \mathrm{HCH}$ in the samples collected from the contrast area (site C) was not significantly lower than that from the sewage outfall area (site A) and the port area (site B), whereas ¿DDT in the samples of the contrast area was relatively lower than that of the other two areas. The distribution suggests that the specimens collected from sites A and B are potentially enriched in higher DDTs relative to those from site $\mathrm{C}$. This affirms that DDT contaminations in Sishili Bay were closely related to industrial and shipping activities. (a)

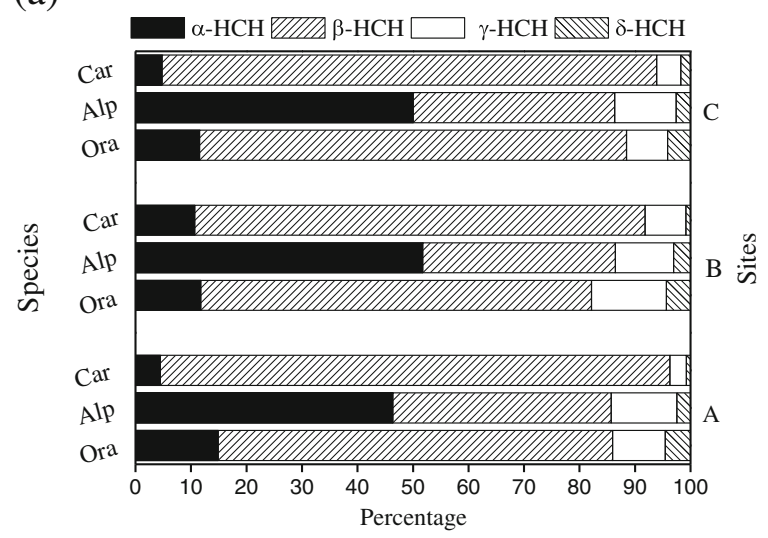

(b)

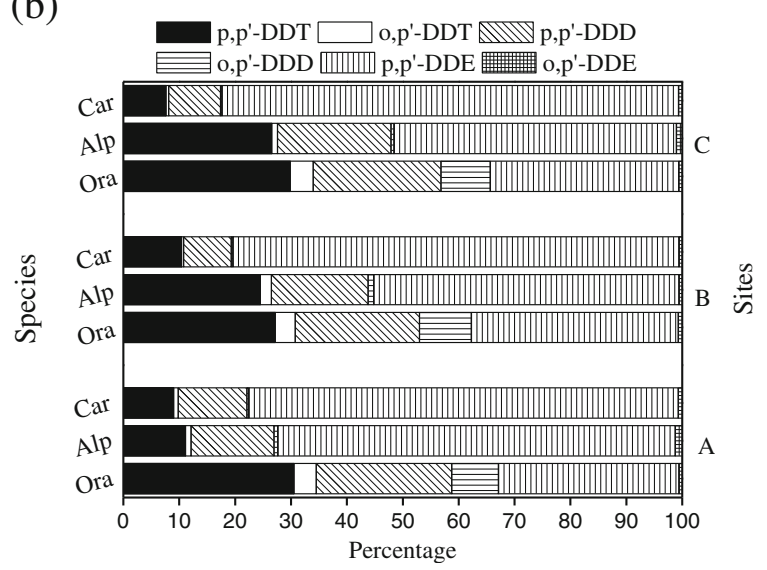

Fig. $3 \mathrm{HCH}$ (a) and DDT (b) compositions in shrimp and crab samples collected from three sampling sites in the Yantai Sishili Bay, China 
Table 3 Other organohalogen concentrations in mollusks (ng g ${ }^{-1}$ d.w.) collected from the seafood market of Yantai Sishili Bay, China

\begin{tabular}{|c|c|c|c|c|c|c|c|}
\hline & Mer. & Chi. & Myt. & Sca. & Cra. & Sol. & Sax. \\
\hline trans-Chlordane & 0.04 & 0.08 & 0.02 & 0.07 & 0.14 & 0.08 & 0.06 \\
\hline cis-Chlordane & 0.015 & 0.094 & 0.057 & 0.039 & 0.117 & 0.057 & 0.039 \\
\hline oxy-Chlordane & nd & 0.05 & 0.03 & 0.06 & 0.04 & nd & 0.03 \\
\hline trans-Nonachlor & 0.034 & 0.166 & 0.077 & 0.128 & 0.166 & 0.123 & 0.039 \\
\hline cis-Nonachlor & nd & 0.03 & 0.02 & 0.03 & 0.08 & 0.03 & 0.01 \\
\hline trans-Heptachlor epoxide & nd & 0.08 & nd & nd & 0.059 & 0.076 & 0.019 \\
\hline cis-Heptachlor epoxide & 0.04 & 0.07 & 0.05 & 0.03 & 0.12 & 0.04 & nd \\
\hline Heptachlor & nd & nd & nd & 0.01 & nd & nd & nd \\
\hline $\mathrm{t}-\mathrm{CHL}^{\mathrm{a}}$ & 0.129 & 0.57 & 0.254 & 0.367 & 0.722 & 0.406 & 0.197 \\
\hline Aldrin & nd & nd & nd & nd & nd & nd & nd \\
\hline Dieldrin & nd & 0.55 & nd & nd & nd & nd & nd \\
\hline Endrin & 0.07 & 0.23 & 0.18 & 0.13 & 0.31 & 0.13 & 0.09 \\
\hline Mirex & 0.06 & 0.08 & 0.04 & 0.08 & 0.05 & 0.23 & 0.02 \\
\hline $\mathrm{HCB}$ & 1.00 & 0.62 & 0.57 & 0.52 & 0.48 & 0.54 & 0.46 \\
\hline $\mathrm{t}-\mathrm{OCP}$ & 1.259 & 2.05 & 1.044 & 1.097 & 1.562 & 1.306 & 0.767 \\
\hline
\end{tabular}

Other OCPs in mollusks

The concentrations of other organochlorine pesticides in mussels are summarized in Table 3. Generally, OCPs were all detected in the analyzed samples, except aldrin. Dieldrin was detected just in Chi. These OCPs were found to be less abundant, either because of their higher water solubility and lower $\log K_{\text {ow }}$ or the fact that their use in agriculture was decreasing (Binelli and Provini 2003). The relatively high levels of these OCPs

Table 4 Comparison of $\sum$ DDT and $\sum \mathrm{HCH}$ concentrations in $\mathrm{Cra}$. (ng $\mathrm{g}^{-1}$ d.w.) between this study and published data

\begin{tabular}{lllll}
\hline Year & Location & $\sum^{2 D T s}{ }^{\mathrm{a}}$ & HHCHs $^{\mathrm{b}}$ & Reference $^{2}$ \\
\hline 2009 & Yellow Sea, China & $20.52-331.3$ & $0.88-8.21$ & Present study \\
1998 & Tokyo Bay, Japan & $5.0-8.0$ & $0.06-0.30$ & Ueno et al. 1999 \\
$1994-1997$ & Southeast estuarine, China & $240-310$ & $0.70-5.4$ & Hong et al. 2000 \\
$1994,1997,1998,1999,2001$ & East coast, China & $14.1-648$ & $0.14-1.85$ & Monirith et al. 2003 \\
& Hong Kong, China & $7.5-1,000$ & $0.02-0.60$ & \\
2001 & Coast, Vietnam & $2.40-310$ & $0.04-0.11$ & \\
2005 & Coast, Cambodia & $0.10-0.20$ & $<0.01$ & Fung et al. 2004 \\
2004 & East coast, China & $14.4-640$ & $0.13-1.86$ & Jin et al. 2008 \\
2004 & Northeast coast, China & $44.0-1,630$ & $1.42-20.4$ & Ramu et al. 2007 \\
2004 & Japan & $1.2-26.6^{\mathrm{c}}$ & $0.55-3.8^{\mathrm{c}}$ & \\
2004 & Hong Kong & $39.6-3,770^{\mathrm{c}}$ & $0.2-1.15^{\mathrm{c}}$ & \\
2004 & Philippines & $33-80.75^{\mathrm{c}}$ & $0.05-0.35^{\mathrm{c}}$ & \\
2004 & Vietnam & $7.55-2,120^{\mathrm{c}}$ & $0.05-0.3^{\mathrm{c}}$ & \\
\hline
\end{tabular}

${ }^{\text {a }}$ Sum of $p, p^{\prime}$-DDT, $p, p^{\prime}$-DDD, and $p, p^{\prime}$-DDE

${ }^{\mathrm{b}}$ Sum of $\alpha-, \beta-$, and $\gamma-\mathrm{HCH}$

${ }^{\mathrm{c}}$ Data on wet weight reported in the original paper was converted into dry weight assuming moisture content as $80 \%$ 
were detected in Chi., followed by Cra., Sol., and Mer., whereas the low concentration of t-OCP was found in S. purpuratus (Sax.). As far as these OCP kinds are concerned, six kinds of OCPs were not found in Mer., and the levels of t-CHL, endrin, and mirex in Mer. were lower than those in other mussels. Among these OCPs, $\mathrm{HCB}$ was predominant with the concentration range of $0.46-1.00 \mathrm{ng} \mathrm{g}^{-1}$, followed by t-CHL. The concentration of HCB was higher than that reported by Tanabe et al. (2000) from the coastal waters of Thailand, Philippines, and India but comparable with the value (0.5-1.0 $\left.\mathrm{ng} \mathrm{g}^{-1}\right)$ found by Solé et al. (2000) from the Ebro Delta bay (Spain). HCB is not directly used in agriculture, but it is a byproduct of some pesticide production and can be released into the environment by leachates or formed during the incineration processes (Binelli and Provini 2003). The concentration range of $\mathrm{t}$-CHL was $0.055-0.297 \mathrm{ng} \mathrm{g}^{-1}$, which was lower than the concentration (0.17-9.91 $\mathrm{ng} \mathrm{g}^{-1}$ ) reported by Fung et al. (2004) in the east coast of China and the concentration (nd-2.28 $\mathrm{ng} \mathrm{g}^{-1}$ ) reported by Jin et al. (2008) in the northeastern coast of China. Some studies reported that $\mathrm{t}-\mathrm{CHL}$ compounds were still used extensively in agriculture, gardens, buildings, etc. (Wong et al. 2005; Lammel et al. 2007); thus, it was not surprising to find higher CHL concentrations in the mollusk samples.

\section{Comparison of HCH and DDT contents in $\mathrm{Cra}$. with other reported data}

To assess the current situation of OCP contamination in marine organisms from the Yantai coastal area, we compared the published data for $\sum \mathrm{HCH}$ and $\sum \mathrm{DDT}$ residues in Cra. from various regions and times (Table 4). It was found that the DDT and $\mathrm{HCH}$ contents varied markedly. In general, their contents in the Cra. from the Yantai coastal area were not very high. In the case of DDT, the total concentration was $20.52-331.3 \mathrm{ng} \mathrm{g}^{-1}$ in this study. The highest EDDT concentrations appeared in Hong Kong, followed by Vietnam and Northeast coast of China, which were, respectively, about 11.4, 6.4, and 4.9 times higher than our report.

The level of total $\mathrm{HCH}$ concentration in Cra. collected from Yantai was lower than those collected from Qingdao, Weihai, and Tianjin as reported by Jin et al. (2008), while it was higher than that reported by Ueno et al. (1999), reflecting relatively higher levels of $\mathrm{HCH}$ in these coastal area in Bohai Sea. The level of
HCHs in Cra. in the present study is similar to those from developing countries such as Benya, Ningo, and Sakumo (Otchere 2005).

\section{Conclusions}

Generally, the bivalve, shrimp, and crab samples collected from Sishili Bay have been contaminated by $\mathrm{HCHs}$, DDTs, and other OCPs. The levels of OCPs in the mollusks purchased from the seafood market of Yantai varied greatly, depending on the OCP isomers and organism species, while the OCP contents in shrimp and crab samples collected from three areas varied in individual species and in sampling sites. The concentration level was not exceeding the edible criteria except the total concentration of DDTs in Cra. To some extent, probable health problems might be encountered in people consuming excessive shrimps, crabs, and mollusks, and more emphasis should be placed on continuous monitoring of these compounds.

Acknowledgments This research was financially supported by the Key Research Program of the Chinese Academy of Sciences (KZZD-EW-14) and the Science and Technology Project of Yantai (2012132).

\section{References}

Binelli, A., \& Provini, A. (2003). POPs in edible clams from different Italian and European markets and possible human health risk. Marine Pollution Bulletin, 46(7), 879-886.

Chopra, A. K., Sharma, M. K., \& Chamoli, S. (2011). Bioaccumulation of organochlorine pesticides in aquatic system - an overview. Environmental Monitoring and Assessment, 173(1-4), 905-916.

Fung, C. N., Lam, J. C. W., Zheng, G. J., Connell, D. W., Monirith, I., Tanabe, S., et al. (2004). Mussel-based monitoring of trace metal and organic contaminants along the east coast of China using Perna viridis and Mytilus edulis. Environmental Pollution, 127(2), 203-216.

Hong, H., Wang, X., Xu, L., Chen, W., Zhang, L., \& Zhang, Z. (2000). Trace organic pollutants in the southeast estuarine environments of China. Journal of Environmental Science and Health, Part A, 35(10), 1833-1847.

Iwata, H., Tanabe, S., Sakal, N., \& Tatsukawa, R. (1993). Distribution of persistent organochlorines in the oceanic air and surface seawater and the role of ocean on their global transport and fate. Environmental Science and Technology, 27(6), 1080-1098.

Jin, Y., Hong, S. H., Li, D., Shim, W. J., \& Lee, S. S. (2008). Distribution of persistent organic pollutants in bivalves from 
the northeast coast of China. Marine Pollution Bulletin, 57(6-12), 775-781.

Klumpp, D. W., Huasheng, H., Humphrey, C., Xinhong, W., \& Codi, S. (2002). Toxic contaminants and their biological effects in coastal waters of Xiamen, China.: I. Organic pollutants in mussel and fish tissues. Marine Pollution Bulletin, 44(8), 752-760.

Lammel, G., Ghim, Y. S., Grados, A., Gao, H., Hühnerfuss, H., \& Lohmann, R. (2007). Levels of persistent organic pollutants in air in China and over the Yellow Sea. Atmospheric Environment, 41(3), 452-464.

Leng, J. H., Kayama, F., Wang, P. Y., Nakamura, M., Nakata, T., \& Wang, Y. (2009). Levels of persistent organic pollutants in human milk in two Chinese coastal cities, Tianjin and Yantai: influence of fish consumption. Chemosphere, 75(5), 634-639.

Liu, W., Chen, J., Hu, J., Ling, X., \& Tao, S. (2008). Multi-residues of organic pollutants in surface sediments from littoral areas of the Yellow Sea, China. Marine Pollution Bulletin, 56(6), 1091-1103.

Liu, Y., Song, C., Li, Y., Liu, Y., \& Song, J. (2012). The distribution of organochlorine pesticides (OCPs) in surface sediments of Bohai Sea Bay, China. Environmental Monitoring and Assessment, 184(4), 1921-1927.

Mai, B. X., Fu, J. M., Sheng, G. Y., Kang, Y. H., Lin, Z., Zhang, G., et al. (2002). Chlorinated and polycyclic aromatic hydrocarbons in riverine and estuarine sediments from Pearl River Delta, China. Environmental Pollution, 117(3), 457-474.

Monirith, I., Ueno, D., Takahashi, S., Nakata, H., Sudaryanto, A., Subramanian, A., et al. (2003). Asia-Pacific mussel watch: monitoring contamination of persistent organochlorine compounds in coastal waters of Asian countries. Marine Pollution Bulletin, 46(3), 281-300.

Otchere, F. A. (2005). Organochlorines (PCBs and pesticides) in the bivalves Anadara (Senilis) senilis, Crassostrea tulipa and Perna perna from the lagoons of Ghana. Science of the Total Environment, 348(1-3), 102-114.

Rajendran, R. B., Imagawa, T., Tao, H., \& Ramesh, R. (2005). Distribution of PCBs, HCHs and DDTs, and their ecotoxicological implications in Bay of Bengal, India. Environment International, 31(4), 503-512.

Ramu, K., Kajiwara, N., Sudaryanto, A., Isobe, T., Takahashi, S., Subramanian, A., et al. (2007). Asian Mussel Watch Program: contamination status of polybrominated diphenyl ethers and organochlorines in coastal waters of Asian countries. Environmental Science and Technology, 41(13), 4580-4586.

Simonich, S. L., \& Hites, R. A. (1995). Global distribution of persistent organochlorine compounds. Science, 269(5232), $1851-1854$

Smeds, A., \& Saukko, P. (2001). Identification and quantification of polychlorinated biphenyls and some endocrine disrupting pesticides in human adipose tissue from Finland. Chemosphere, 44(6), 1463-1471.

Solé, M., Porte, C., Barcelo, D., \& Albaiges, J. (2000). Bivalves residue analysis for the assessment of coastal pollution in the Ebro Delta (NW Mediterranean). Marine Pollution Bulletin, 40(9), 746-753.

Szlinder-Richert, J., Barska, I., Mazerski, J., \& Usydus, Z (2008). Organochlorine pesticides in fish from the southern Baltic Sea: levels, bioaccumulation features and temporal trends during the 1995-2006 period. Marine Pollution Bulletin, 56(5), 927-940.

Tanabe, S., Iwata, H., \& Tatsukawa, R. (1994). Global contamination by persistent organochlorines and their ecotoxicological impact on marine mammals. Science of the Total Environment, 154(2-3), 163-177.

Tanabe, S., Prudente, M. S., Kan-atireklap, S., \& Subramanian, A. (2000). Mussel watch: marine pollution monitoring of butyltins and organochlorines in coastal waters of Thailand, Philippines and India. Ocean \& Coastal Management, 43(8-9), 819-839.

Ueno, D., Takahashi, S., Tanabe, S., Ikeda, K., \& Koyama, J. (1999). Uptake kinetics of persistent organochlorines in mussels through the transplantation experiment. Journal of Environmental Chemistry, 9, 369-378.

Wan, Y., Hu, J. Y., Liu, J. L., An, W., Tao, S., \& Jia, Z. B. (2005a). Fate of DDT-related compounds in Bohai Bay and its adjacent Haihe Basin, North China. Marine Pollution Bulletin, 50(4), 439-445.

Wan, Y., Hu, J. Y., An, L. H., An, W., Yang, M., Mitsuaki, I., Tatsuya, H., \& Tao, S. (2005b). Determination of trophic relationships within a Bohai Bay food web using stable delta $\mathrm{N}-15$ and delta C-13 analysis. Chinese Science Bulletin, 50(10), 1021-1025.

Willett, K. L., Ulrich, E. M., \& Hites, R. A. (1998). Differential toxicity and environmental fates of hexachlorocyclohexane isomers. Environmental Science and Technology, 32(15), 2197-2207.

Wong, M. H., Leung, A. O. W., Chan, J. K. Y., \& Choi, M. P. K. (2005). A review on the usage of POP pesticides in China, with emphasis on DDT loadings in human milk. Chemosphere, 60(6), 740-752.

Wu, W. Z., Xu, Y., Schramm, K. W., \& Kettrup, A. (1997). Study of sorption, biodegradation and isomerization of $\mathrm{HCH}$ in stimulated sediment/water system. Chemosphere, 35(9), 1887-1894.

Yang, R. Q., Yao, Z. W., Jiang, G. B., Zhou, Q. F., \& Liu, J. Y. (2004). HCH and DDT residues in molluscs from Chinese Bohai coastal sites. Marine Pollution Bulletin, 48(7-8), 795-799.

Yang, Y., Liu, M., Xu, S., Hou, L., Ou, D., Liu, H., et al. (2006). $\mathrm{HCHs}$ and DDTs in sediment-dwelling animals from the Yangtze Estuary, China. Chemosphere, 62(3), 381-389.

Zhang, G., Parker, A., House, A., Mai, B. X., Li, X. D., Kang, Y. H., et al. (2002). Sedimentary records of DDT and HCH in the Pearl River Delta, South China. Environmental Science and Technology, 36(17), 3671-3677.

Zhang, P., Song, J., \& Yuan, H. (2009). Persistent organic pollutant residues in the sediments and mollusks from the Bohai Sea coastal areas, North China: an overview. Environment International, 35(3), 632-646. 